\title{
Socio-Demographic Impact Study of Nepal Earthquake 2015 at Sindhuli District
}

\author{
Bishnu B. Khatri \\ Central Department of Rural Development Studies, Tribhuvan University (TU), Kathmandu, Nepal \\ Email: Khatri.bishnu@cdrd.edu.np, Khatri.bishnu@gmail.com
}

How to cite this paper: Khatri, B.B. (2018) Socio-Demographic Impact Study of Nepal Earthquake 2015 at Sindhuli District. Open Journal of Earthquake Research, 7, 53-68. https://doi.org/10.4236/ojer.2018.71004

Received: January 2, 2018

Accepted: February 25, 2018

Published: February 28, 2018

Copyright $\odot 2018$ by author and Scientific Research Publishing Inc. This work is licensed under the Creative Commons Attribution International License (CC BY 4.0).

http://creativecommons.org/licenses/by/4.0/

\begin{abstract}
As a result of the two major earthquakes that struck Nepal at 11:56 am on 25 April, and 12 May 2015, nearly 9,000 lives and over half a million homes have been destroyed. In this connection, the paper tries to assess the socio-demographic impact of Nepal earthquake 2015 with reference to Sindhuli district. The Sindhuli district of Nepal was one of the highly affected districts among the fourteen severely destructed districts of the central part of Nepal, was purposively selected among them for the study purpose. The paper utilized the both primary and secondary data. The survey found that the earthquakes had unevenly affected the age, gender, poorer, rural locations relative to the urban and less poor areas. It also found that women and children had comparatively fallen victim to anxiety, trauma, depression, feeling helpless, loss of interest (passive) and irrational fear. During the survey, the study found that the NGOs, INGOs, Private and Personal support agencies/actors had played significant role in distribution of relief package at Sindhuli district of Nepal. The distributions of relief materials were challenging because of lack of road connectivity to reach at many earthquake affected villages in Sindhuli district.
\end{abstract}

\section{Keywords}

Socio-Demographic, Impact, Nepal Earthquake 2015, Sindhuli District

\section{Introduction}

Historical records show that Nepal has long suffered from various types of disasters. Nepal is among the 20 most disaster-prone countries in the world. More than 80 percent of the total population of Nepal is at risk of natural hazards such as floods, landslides, windstorms, hailstorms, fires, earthquakes and Glacial Lake Outburst Floods (GLOFs) [1]. Like many nations in terms of vulnerability of 
earthquakes, Nepal is a developing nation in a seismically active plate boundary zone. Globally, Nepal ranks 4th and 11th in terms of its relative vulnerability to climate change and earthquakes, respectively [1] [2].

Moreover, Nepal earthquake 2015 was unique in its own way. The tremor first took place around 11:56 AM on April 25, 2015 and more than 300 aftershocks went on unabated thereafter and continued till the date with an average magnitude greater than of 4.0 Richter scale. Severe tremors did hit Nepal in the past as well. The first such tremor hit took place in 1255 AD killing one-third of the population of the Kathmandu valley including the King Abhaya Malla and second time in $1934 \mathrm{AD}$ with a magnitude of 8.4 Richter scale causing more than 10,000 deaths again in the Kathmandu valley itself. Besides these two recorded devastating quake episodes, Nepal had faced several such shaking experiences but of lesser kinds (in terms magnitude and damages caused) during 1980, 1988 and in 2011 [3] [4] [5]. Nepal should have learned lesson, where the nation had gone through severe disaster and had tremendously impacted the social, culture and economical sector overall [6]. Table 1 shows the losses due to earthquake and other disasters in different period of time [5].

Table 1. Major earthquakes in Nepal in last 100 years.

\begin{tabular}{|c|c|c|c|c|}
\hline Year & Location & Magnitude & Damages & Cost \\
\hline 1934 & Nepal & 8.4 & $\begin{array}{l}\text { - 10,700 dead } \\
\text { - } 126,355 \text { houses damaged } \\
\text { - 80,893 buildings destroyed }\end{array}$ & $\begin{array}{l}206500 \text { rupees } \\
\text { (Kathmandu Valley only) }\end{array}$ \\
\hline 1980 & $\begin{array}{l}\text { Baitadi } \\
\text { Bajhang Darchula }\end{array}$ & 6.5 & $\begin{array}{l}\text { - } 125 \text { dead } \\
-248 \text { seriously injured } \\
-13,414 \text { buildings damaged } \\
\text { - 11,604 buildings destroyed }\end{array}$ & Unknown \\
\hline 1988 & $\begin{array}{l}\text { Eastern Development Region } \\
\text { Some Parts of Central Development Region }\end{array}$ & 6.8 & $\begin{array}{l}-721 \text { dead } \\
-6,553 \text { injured } \\
\text { - } 65,432 \text { buildings damaged } \\
-1,566 \text { livestock dead } \\
\text { - } 22 \text { districts of eastern Nepal affected }\end{array}$ & 5 billion rupees \\
\hline 1993 & Central Region Midwestern Region & Unknown & $\begin{array}{l}-1 \text { dead } \\
-11 \text { injured } \\
-72 \text { houses destroyed } \\
-451 \text { buildings damaged }\end{array}$ & 48.39 million rupees \\
\hline 1994 & Midwestern Region & Unknown & $\begin{array}{l}-12 \text { injured } \\
-623 \text { affected } \\
-84 \text { houses destroyed } \\
-287 \text { buildings damaged }\end{array}$ & 16.35 million rupees \\
\hline 1997 & $\begin{array}{l}\text { Central Region } \\
\text { Far Western Region }\end{array}$ & Unknown & $\begin{array}{l}-1 \text { injured } \\
-1,489 \text { affected } \\
-196 \text { houses destroyed } \\
-60 \text { buildings damaged }\end{array}$ & 51.29 million rupees \\
\hline 2015 & Northwest of Kathmandu & 7.8 & $\begin{array}{l}\text { As of May } 25,2015: \\
8,669 \text { deaths } \\
16,808 \text { injured } \\
288,793 \text { buildings damaged } \\
254,114 \text { building partially damaged }\end{array}$ & TBD (To be declared) \\
\hline
\end{tabular}


The major earthquakes of 25 April and 12 May, 2015 have severely destructed to the fourteen districts of central part of Nepal. Damage is estimated at about $1 / 3$ of Nepal's GDP [7]. According to PDNA report (NPC, 2015), Sindhuli district is one of the highly affected districts among them in terms of their degrees of devastation. Therefore, Sindhuli district is chosen to screening survey for purpose of socio-demographic impact study.

Socio-demographic Information of Sindhuli District. Nepal has experienced demographic growth with a more than threefold increase of the population, from 8.3 million to 26.5 million people, over the last six decades [8] [9]. Sindhuli is geographically large mid-mountainous district situated in Janakpur Zone of Central development region of Nepal. The area of the district is 2491 Sq. $\mathrm{km}$. According to the report of the National Census 2011, the population of Sindhuli is 296192. It represents 1.12 percent of total population of Nepal [9]. Sindhuli district consists of 2 Municipality (Kamalamai Municipality and newly developed Dudhauli Municipality) and 50 Village Development Committees (VDCs). The neighbor districts of the Sindhuli in Nepal are Ramechap, Okhaldhunga, Udayapur, Siraha, Dhanusha, Mahottari, Rautahat, Sarlahi, Makwanpur and Kavreplanchok. District headquarter is located in the Sindhulimadhi.

Tamang, Chhetri, Magar, Brahman and other scheduled castes are habitant of the district. In this district, the population of Majhi, Danuwar and Hayu have highest as compared to the other district of Nepal. The population density of this district is the lowest among the mountainous district of the central development region. Most of the (about 90\%) people believe Hindu religion and rest of the people believes Buddhist, Kirat, Christian and others [10].

Livestock plays a better role along with agriculture. Rice is the main food crop of this district. Wheat, Maize, Kodo, Patato are the other cereals product of the district. The district is popular for Junar (a sweet fruit). The black topped road facility has not reached for all the VDCs. This district has only $94 \mathrm{~km}$ length of the road which shows it's very difficult to reach by bus all the VDCs of the district. Most of the areas of this district remain to develop not only by the means of communication but also other types of infrastructures. There are 3 Primary Health Care Centers, 17 Health Posts and 35 Sub-health posts existing in each VDCs [11]. Table 2 reflects the principal development indicators of Sindhuli district [12] and Table 3 shows the general demographic information of Sindhuli district [9].

Table 2. Principal indicators of Sindhuli district.

\begin{tabular}{cc}
\hline Indicators & Value \\
\hline Human Development Index & 0.469 \\
Human Poverty Index & 48.3 \\
Income Index & 0.397 \\
Educational Attainment Index & 0.326 \\
Social Empowerment Index & 0.385 \\
Political Empowerment Index & 0.506 \\
Economic Empowerment Index & 0.100 \\
\hline
\end{tabular}


Table 3. Demographic information of Sindhuli district.

\begin{tabular}{lclc}
\hline \multicolumn{1}{c}{ Indicators } & Total & \multicolumn{1}{c}{ Male } & Female \\
\hline Population & 296192 & 142123 & 154069 \\
Absent (abroad) population & 15287 & 14003 & 1284 \\
Sex ratio & 92.2 & Male per 100 females & \\
Population density & 119 & Person per sq. km. & 57581 \\
Annual growth rate & $0.58 \%$ & Number of households & 5.4 \\
Decadal population change & $5.85 \%$ & Average household size & $39.18 \%$ \\
Under 5 years population & $10.44 \%$ & Under 15 years population & \\
>60 years population & $7.97 \%$ & Population Dependency & $47.15 \%$ \\
Economically active population & $52.85 \%$ & Average Life expectancy & 66.05 years \\
\hline
\end{tabular}

\section{Objectives}

The general objective of the study is to examine the socio-demographic impact study of Sindhuli district after Nepal earthquake 2015 through screening survey.

- To explore the secondary data aftermath of earthquake that DDRC has produced the data relating to human as well as physical loss.

- To examine the socio-demographic situation at severely hit, moderately hit and the least hit area of the district.

\section{Significance of the Study}

Nepal has been ranked by the UNDP (2009) as the $11^{\text {th }}$ position in the world in terms of vulnerability to earthquakes [2]. However, Nepal was struck with a catastrophic earthquake of magnitude 7.8 on 25 April 2015 causing a significant loss of life and property. The thirty one districts in Central Nepal were affected among which 14 districts suffered worst damages [7]. The large earthquakes that hit central parts of Nepal not only led to huge damage and loss of lives but also brought the country to the limits of successful disaster management. Therefore, it appears necessarily significant and timely to examine closely to a detailed inventory of damage and loss caused by the recent earthquakes and associated relief and resettlement activities.

\section{Materials and Methods}

The study has designed the mix-methods to fulfill the study purposes. The study is based on descriptive research design in nature. Therefore, the study was focused to generate quantitative and qualitative data from the field screening survey. The quantitative data were collected with the help of district line agencies (DDRC, DDC, WCO, DPHO, DEO, Veterinary office, Agricul- 
ture office etc.) records as secondary information. However, the primary data i.e. the qualitative data were employed by using key informant interview (KII) and focus group discussions (FGDs) with the help of given guidelines and checklists. The data were collected from 21 August to 31 August, 2015 with help of two researchers.

During the screening survey, one KII and three FGDs were conducted at different places of Sindhuli district. One KII was conducted with DDRC member (Planning Officer) at DDC office of Sindhuli district. However, one FGD with female group (including Para-psychological counselor, child right officer, Supervisors, Volunteers) was conducted at Women and Child Development Office (WCO) in district headquarter. There were 8 participants in the focus group discussion. Similarly, One FGD with mothers' group was conducted at Dadagaun, Basheswor village Development Committee (VDC) Ward No. 9 of Sindhuli district. There were 10 participants in the focus group discussion. At last, One FGD with representatives of the society (Male group) was conducted at Sitalpati Village Development Committee Ward No. 2 of Sindhuli district (Figure 1). There were 9 participants in the focus group discussion. Then, the collected data were analyzed and discussed in simple statistical and textual form.

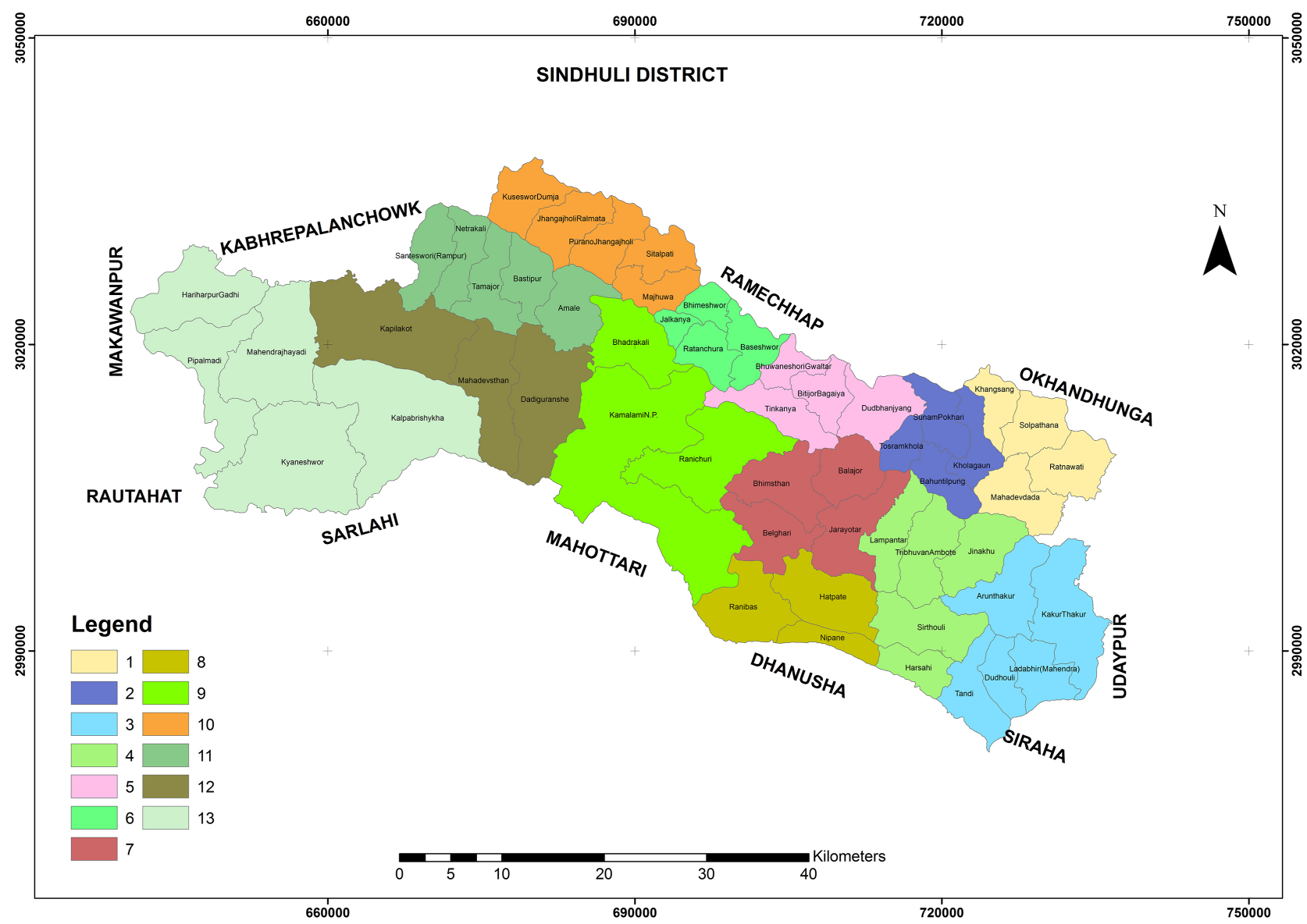

Figure 1. Location map of Sindhuli district of Nepal (Highly affected district of Earthquake 2015). 


\section{Results and Discussions}

The collected data are broadly divided into two categories such as quantitative and qualitative information to analyze and discussion. The first part deals about the secondary data which are presented and discussed as quantitative information in the below.

\subsection{Part I-Quantitative Information}

\subsubsection{Earthquake Affected Area \& Households}

The Sindhuli district comprises 50 VDCs and 2 Municipalities. The District Disaster Relief Committee (DDRC) of Sindhuli has divided into two broad categories to the earthquake affected areas: severely affected and slightly affected areas. DDRC has categorized the affected areas and households on the basis of household damage. Among the VDCs and municipalities, Table 4 shows that about half of the areas were severely affected areas and half of the areas were slightly affected areas by the earthquake in the Sindhuli district. The total affected population was about 1.90 lakh and the total earthquake affected households were 41677 in number. Among the total affected households, 30307 households were severely affected and 11370 households were least affected by the earthquake according to preliminary records of DDRC [13].

Table 4. Distribution of earthquake affected area and households.

\begin{tabular}{cccr}
\hline \multicolumn{2}{c}{$\begin{array}{c}\text { Earthquake Affected VDCs } \\
\text { and Municipalities }\end{array}$} & \multicolumn{2}{c}{$\begin{array}{c}\text { Earthquake Affected Households } \\
\text { in Number }\end{array}$} \\
\hline Severely Affected Area & 25 VDCs (50\%) & Severely Affected Households & 30307 \\
Slightly Affected Area & 25 VDCs and 2 Na. Pa. & Least Affected Households & 11370 \\
Total Affected Population & About 190 Thousands & Total Affected Households & 41677 \\
\hline
\end{tabular}

\subsubsection{Physical Loss \& Damage}

The effects of earthquake are spread unevenly between public and private sectors. According to DDRC record, 73 percent private houses were completely damaged and 27 percent private houses were partially damaged by the earthquake in total damage private houses (41677). Among the institutional/Government houses (534), 88 percent houses were partially damaged and only 12 percent houses were completely damaged in the Sindhuli district. Table 5

Table 5. Distribution of loss and damage of private and institutional houses.

\begin{tabular}{lcc}
\hline \multicolumn{1}{c}{ Loss and Damage Houses } & Number & Percent \\
\hline Completely Damage Houses & 30307 & 73 \\
Partially Damage Houses & 11370 & 27 \\
Total Affected Private Houses & 41677 & 100 \\
Loss and Damage of Institutional Houses & & \\
Completely Damage Houses & 65 & 12 \\
Partially Damage Houses & 469 & 88 \\
Total Affected Institutional/Governmental Houses & 534 & 100 \\
\hline
\end{tabular}


reflects the loss and damage of private and institutional houses in the study area [13].

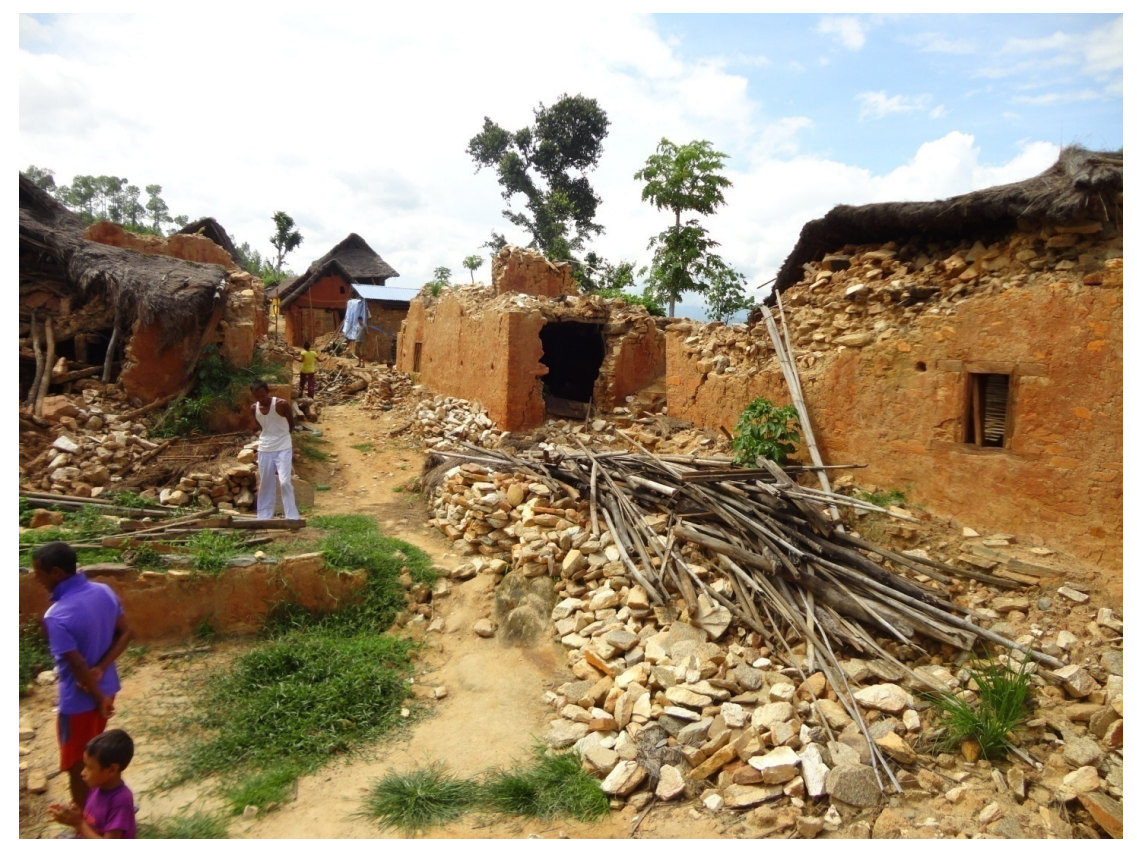

Photo: Completely Damaged Private Houses at Basheswor-9, Dadagaun of Sindhuli District.

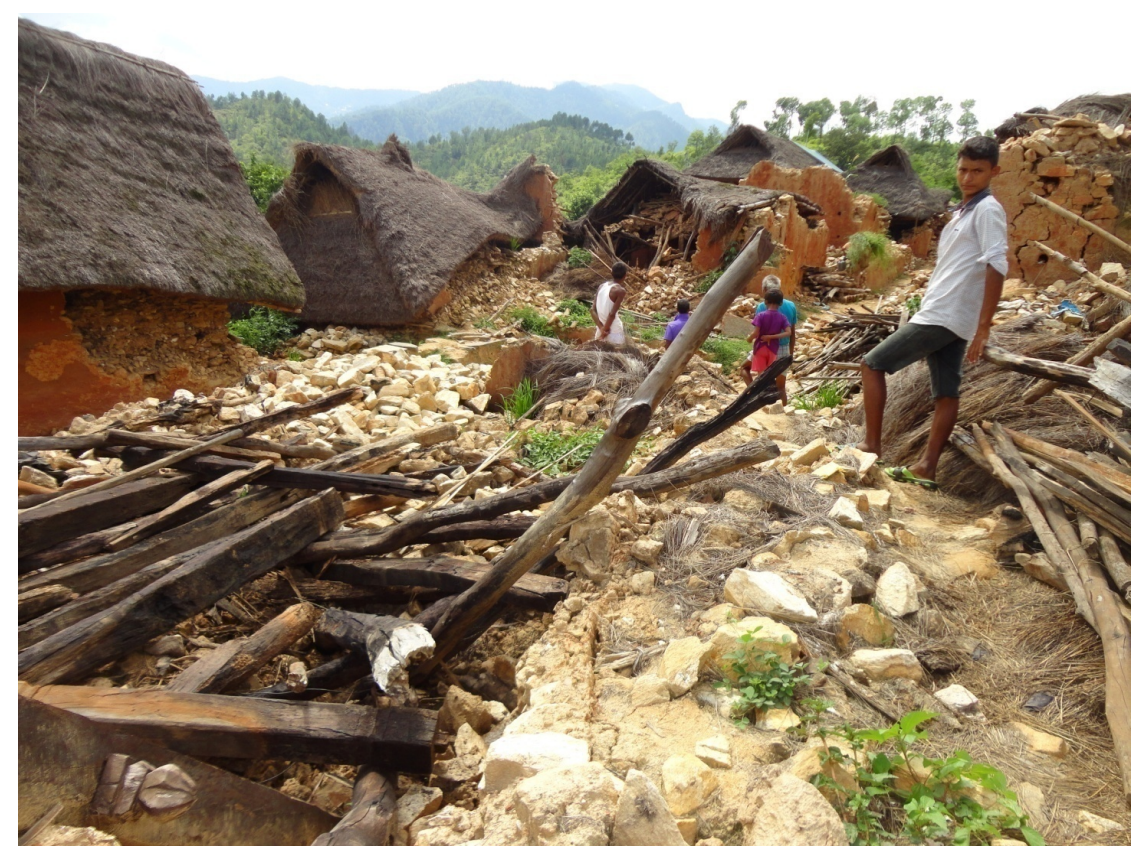

Photo: Completely Damaged Private Houses at Sitalpati VDC-2 of Sindhuli District.

\subsubsection{Human Death \& Injuries}

According to DDRC record [13], 35 people were death. Among them, 15 people were death in this district and 19 people were death in out of district. In total (34), 23 death people were female and 11 death people were male. Two hundred people were severely injured by the earthquake in the Sindhuli district [13] (Table 6). 
Table 6. Distribution of human death and injuries.

\begin{tabular}{ccc}
\hline Place of Death & Number & Percent \\
\hline Death in District & $15(5$ Male \& 10 Female $)$ & 44.2 \\
Death out of District & $19(6$ Male and 13 Female $)$ & 55.8 \\
Total Death & $34(11$ Male \& 23 Female $)$ & 100 \\
Total Severely Injured & 230 & - \\
\hline
\end{tabular}

\subsubsection{Livestock Death \& Injuries}

The DDRC of Sindhuli had recorded the livestock death and injuries. According to Table 7, two hundred ninety one Chaupaya (four footed animals-Ruminents) were deaths in total. Out of the total injuries (31), 28 Chaupaya were severely injuries and 3 Chaupaya were slightly injuries. The total death of Dopaya (two legged-Aves) were 4865 [13].

Table 7. Distribution of livestock death and injuries.

\begin{tabular}{lc}
\hline \multicolumn{1}{c}{ Death and Injuries of Livestocks } & Number \\
\hline Total Deaths of Chaupaya (Four Footed Animals - Ruminents) & 291 \\
Severely Injuries & 28 \\
Slightly Injuries & 3 \\
Total Deaths of Dopaya (Two Legged - Aves) & 4865 \\
\hline
\end{tabular}

\subsubsection{Rescue, Relief and Rehabilitation Activities in Sindhuli District} The DDRC of Sindhuli had responded quickly and mobilized the supporting forces in the affected area for the immediate rescue. According to the DDRC record [13], Table 8 reveals that total 1393 official people were mobilized 24 hours in the earthquake affected area for the rescue of the people. Among them, highest numbers ( 680 people) were from Nepal army, followed by Nepal Police force (402) and civil serviceman (112).

Table 8. Human resource mobilization for rescue activities from the government of Nepal.

\begin{tabular}{ccc}
\hline Mobilized Official People & Number & Remarks \\
\hline Civil Serviceman & 112 & 40 from Central Level \\
Nepal Police Force & 402 & - \\
Nepal Army & 680 & 40 from VDC Level \\
Armed Police Force & 86 & - \\
Local Government Officials & 101 & Mobilized from NPC \\
Volunteers & 12 & - \\
Total & 1393 & \\
\hline
\end{tabular}


The DDRC of Sindhuli had managed the relief package from one door government policy. Table 9 shows the relief and resettlement activities by the side of Nepal government. According to DDRC record [13], it has distributed NRs. 2580000 in total to the death family from the government relief fund until now. Among them, DDRC has distributed NRs. 1380000 to the family who had death in districts and NRs. 1200000 to the family who had death in out of district. However, NRs. 109500000 amount money is distributed for 7000 households (1 Municipality and 22 Village Development Committees) to construct temporary settlements from the government side. The distributed materials and money by non state actors (INGOs, NGOs, Individuals etc.) are not found in actual amount. Emergency relief and humanitarian assistance to the affected population was provided with the active support of and contribution by multi donor agencies, INGOs, NGOs, private agencies and individuals. The distribution of relief materials were challenging because of the remoteness of many villages.

Table 9. Relief and resettlement activities from the government of Nepal.

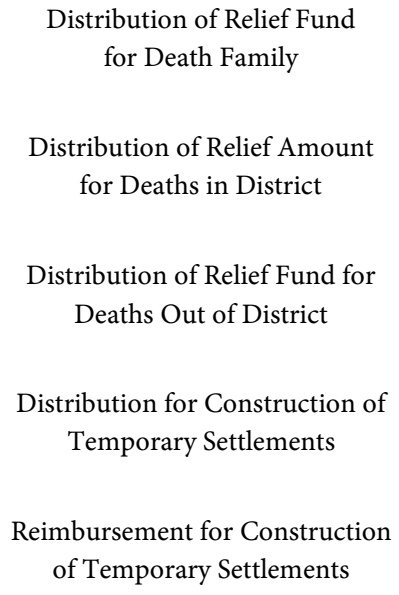

NRs. 2580,000

NRs. 1380000

NRs. 1200,000

NRs. 109500000 (for 7300 households, 1 Municipality \& 22 VDC)

NRs. 163645000

(1 Municipality \& 25 VDC)

\subsection{Part II-Qualitative Information}

Second part deals about the first-hand information generated from the three FGDs and one KII in the below.

FGD-1: Focus Group Discussions at Women and Children Development Office, Sindhuli (28 August, 2015)

The focus group discussion was conducted in the Women and Children Development Office in Sindhuli district, the discussion was basically focused on women and children issues and their vulnerabilities after earthquakes. There were four female participants including child right officer, para-psychological counselor, supervisor and volunteer. Mainly the participants opined the following issues.

Firstly, one participant (she is one of earthquake survivor) narrated in her perception on earthquake disaster that 25 April, 2015 was saturday, started out as other ordinary Saturday. No one would've ever thought of the devastating 
disaster, surprisingly and unexpectedly hit earth at this moment, totally we were soundless, did not move mentally and physically. After few minutes of earthquake, many people lost their houses, families, children and many more. Another participant added her view and said "women and children are more suffered and vulnerable among them". She expressed her opinion that she visited and observed the affected area, and found that women and children have comparatively fallen victim to anxiety, trauma, depression, feeling helpless, loss of interest (passive) and irrational fear. Children did not go to school because they felt helpless.

About 75 percent households are damaged by earthquake hit and few people are death and most of the people have faced injury problems. On the context of rescue and relief in discussion, they said "state and non state actors are completely mobilized in this district and supported to the victims as soon as possible but not sufficient until now because the most of the area are remote and destroyed more". They added, some of the settlement such as Dadagaun, Dumja, Majuwa etc. are highly damaged and affected by earthquake hit. So the government should think to resettlement for those households/areas but earthquake survivors has ignored such proposal because they argue that the change in place will diminish their socio-cultural norms and values. After earthquake, economic status of earthquake survivors and their regular activities (planting, cultivation, harvesting etc.) are deteriorating because they are not completely return in their regular work. So that, they are confuse to plan for celebration of festivals in the future too.

Internal displacement is not prevalent and they set up their temporary houses/sheds in their surroundings, they expressed. Especially, adolescent girls and menstruation women had faced problems than others in the shed because of congestion and limited space. There is no separate room to change clothes and all are sleeping commonly. Women also faced pregnancy complication and did not continue the temporary method of family planning. The gap between the rich and poor is increased by earthquake hit because those people who had only one house as property that was completely loss. But there was slightly increase in solidarity among them. The support activities are increased by NGOs and INGOs to earthquake survivors. UNFPA has distributed dignity Kits for women as well as build RH camp in many villages and other organizations have distributed accommodation materials such as Tents, Tripal, Zinc plate, Rice, Vegetables, Dal (Lenntils), Clothes, Salt, Chiura etc. Some of the NGOs have conducted Child Playing Centre and Counseling Centre for earthquake survivors. The role of INGOs and NGOs and their activities are very praiseworthy at this moment. But the community based organizations (mothers groups, youth clubs, Gumba etc.) did not show their role to organize and activate in this area for the support to earthquake survivors.

FGD-2: Focus Group Discussions with Mother's Group at Basheswor VDC-9, Dadagaun in Sindhuli (29 August, 2015) 
At the time of focus group discussion, mothers' group were gather for the preparation of marriage ceremony in Chautari, near to settlement, Dadagaun but they were not happy, feeling helpless and hopeless, and fearing from earthquake. When we reached there and they asked us horribly, Sir today earthquake will come, is it true (ho ra sir)? We were also surprise and we also questioned them, why and how did you know? They said today is Saturday and 12th date of the month, happened the earthquake in the same date and day in Baisakha (name of the Nepali month), so we are fear and depressed by earthquake. They added that today is our festival Janaipurnima "Rakchabandan" we did not celebrate the "Rakchhabadan" also. Because Our Guru did not come here, she said. "Our village is very risky place and earthquake prone area", Guru says. It showed that the earthquake rumors were highly prevalent in this area.

There was found two elderly women death and hundred percent houses were completely damaged by the earthquake. We continued our discussion and diverted them on rescue and relief package. They said we all got NRs 15000 from the government to make temporary shelter and death family got NRs 140000 too. They say, "All people utilized this money for shelter making especially to buy Zinc plate". The police force presented for support within 3 hours after earthquake. The police and army had supported to remove damage houses and to clean debris as well as shelter making, they said.

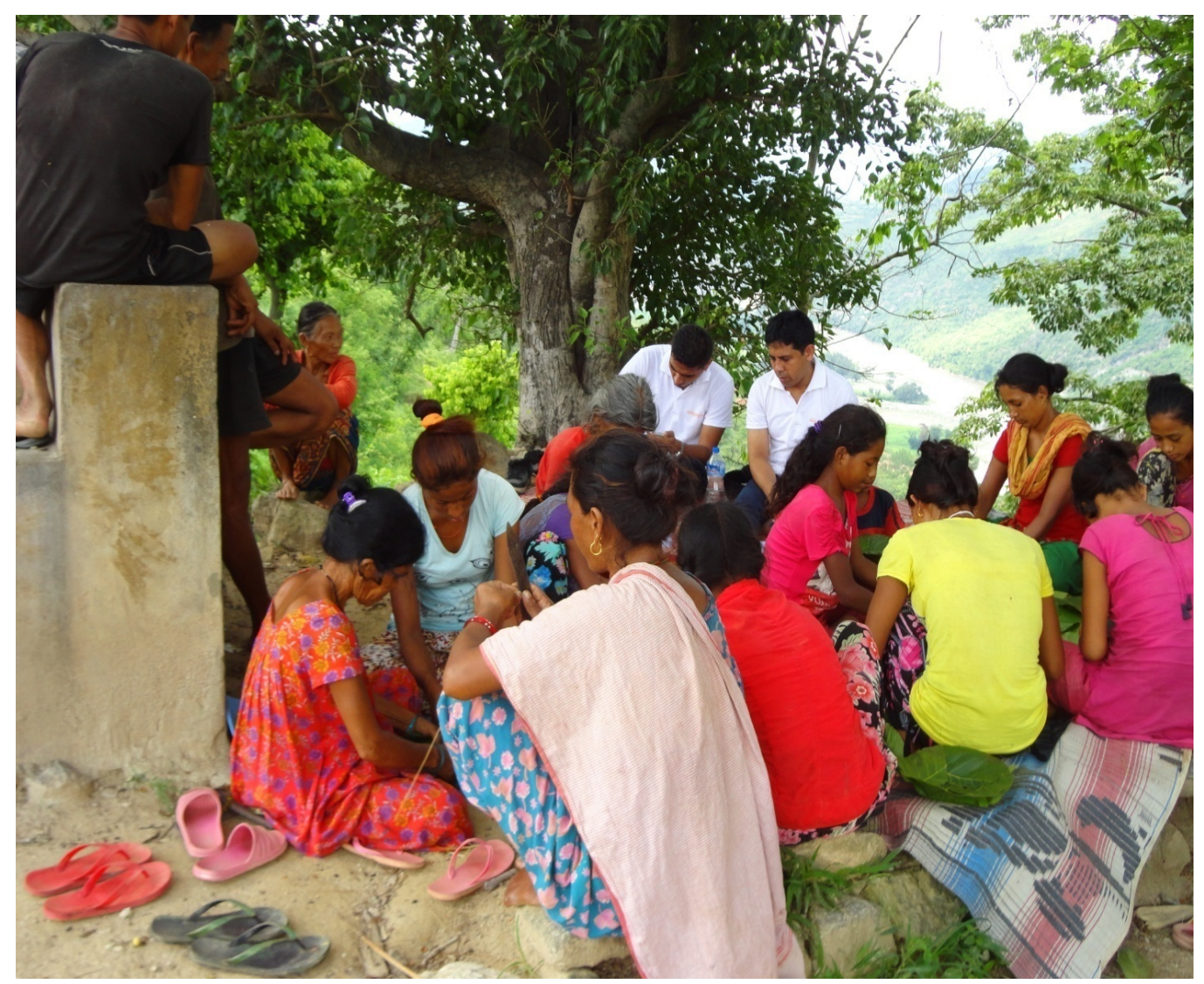

Photo: Focus Group Discussion with Mother's group at Basheswor VDC-9 of Sindhuli district 


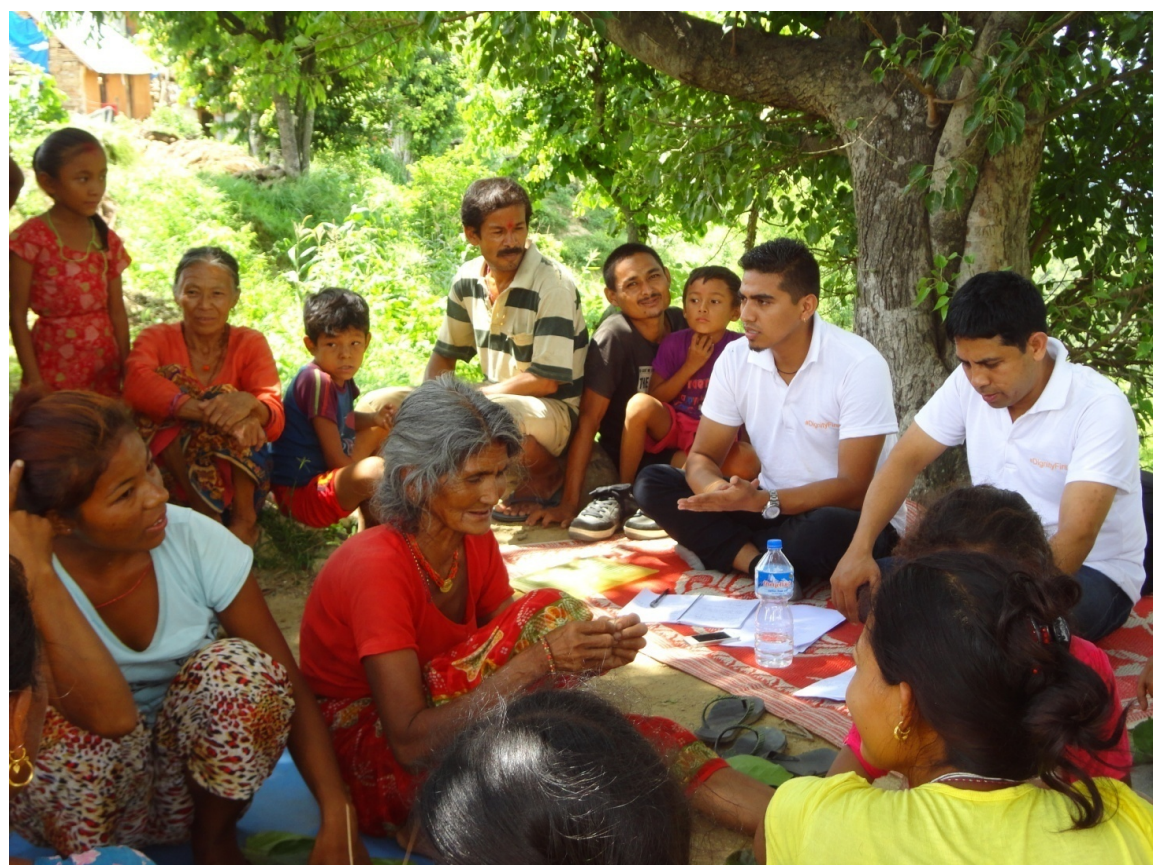

Photo: Focus Group Discussion with Mother's group at Basheswor VDC-9 of Sindhuli District

They did not cultivated peanuts this time because of earthquake hit. They are not returned in work completely until now because of depression and fear of earthquake. After earthquake, some of them reduced the cattle because of lack of farm house and they have experienced store room lacking for seeds and food storage.

There were no any incident/record of girl trafficking and migration, they said. Mainly they felt psychological problems. Among them, women, children, disable people and elderly people were more affected and suffered by earthquake. They reported that 2 women and 3 children were unconscious time to time. They are feeling/experiencing shaking hand, fear, vomiting, headache, hopeless, helpless and depression. They said during the discussion, adolescent girls and women had faced multiple problems in menstruation period and sleeping, bathing and clothing time. In the observation of settlement, all houses were completely damaged and temporary shelters were made very congested with poor sanitation.

FGD-3: Focus Group Discussions with Village Representatives at Sitalpati VDC-2, Chainpur in Sindhuli (30 August, 2015)

During the discussion with the participants of Chainpur village, they reported that about 50 percent households were completely damaged by the earthquake in this village. After earthquake, the rescue team from district came there very late and did not support well. They added here is no well coordination in relief package distribution between the government and stakeholders and distribution is halted by government because of political conflict and duplication of household damage record as well as administrative inefficiency of VDC secretary. VDC secretary is new and no idea in work, they added. They said the children are suffering from psychological problems, such vomiting, anxiety, headache; 
fear etc. children did want to go to school after earthquake. They reported that the role and contribution of INGOs, NGOs and other agencies is very poor. They did not face sexual exploitation and human trafficking in this area. "Internal displacement was not found here", they said.

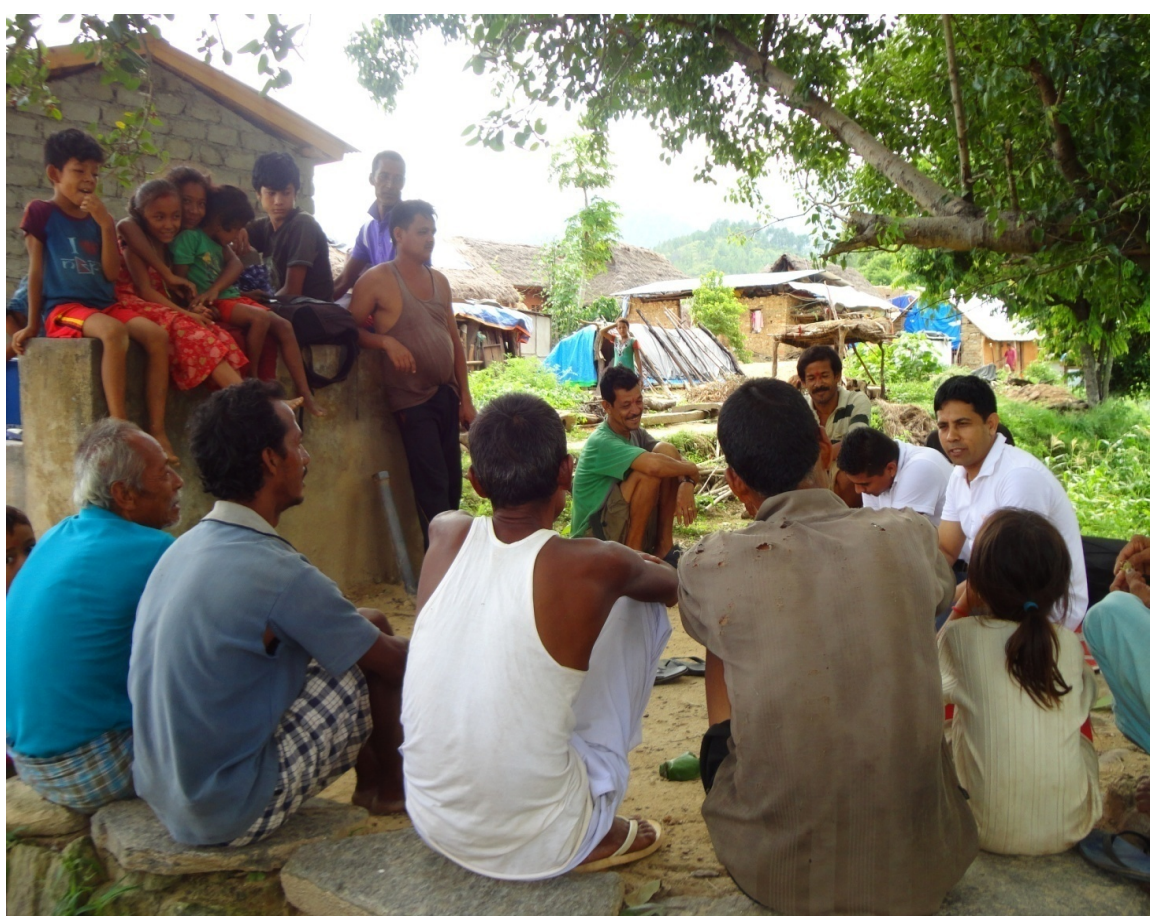

Photo: Focus Group Discussion with Village Representatives (Male group) at Sitalpati VDC-2

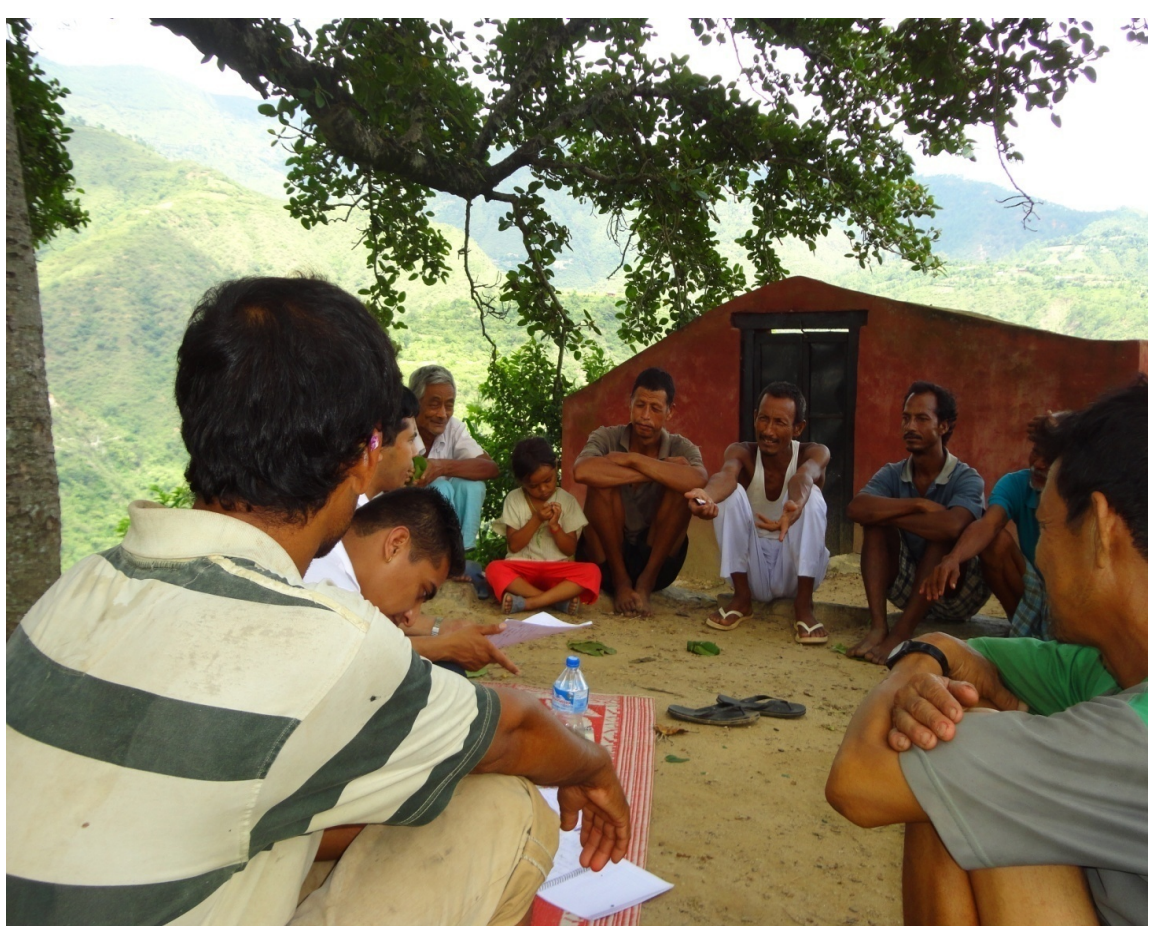

Photo: Focus Group Discussion with Village Representatives (Male group) at Sitalpati VDC-2 of Sindhuli district 


\section{KII-1: Key Informant Interview with Planning Officer at DDC in Sindhuli} (31 August, 2015)

Sagar Dhakal (Planning Officer) reported that the DDRC had quickly responded the earthquake affected area for the support and rescue of the earthquake victims/survivors after earthquake. He added that police force was reached within half an hour at earthquake affected area. According to the preliminary record of DDRC, about 75 percent houses are damaged and 15 people are death and about 7000 people are injured in this district by earthquake hit. DDRC has recorded data in two classifications to damage houses: completely damage and partially damage. About fifty percent of VDCs are severely affected by earthquake; they are classified on the basis of house damages.

For rescue and relief, the DDRC has mobilized Nepal Army, Nepal Police force, Armed Police force (for 24 hours), civil serviceman, other government officials and institutional partners/district line agencies as well as non-state actors in the earthquake affected areas. He added that DDRC has followed government one door policy for the distribution of relief package and made 12 clusters for relief package distribution. The government has distributed NRs 15000 for each family who lost house and NRs. 140000 for member of the death family. However, the government has apportioned a budget to assist those who lost their livestock to the quake.

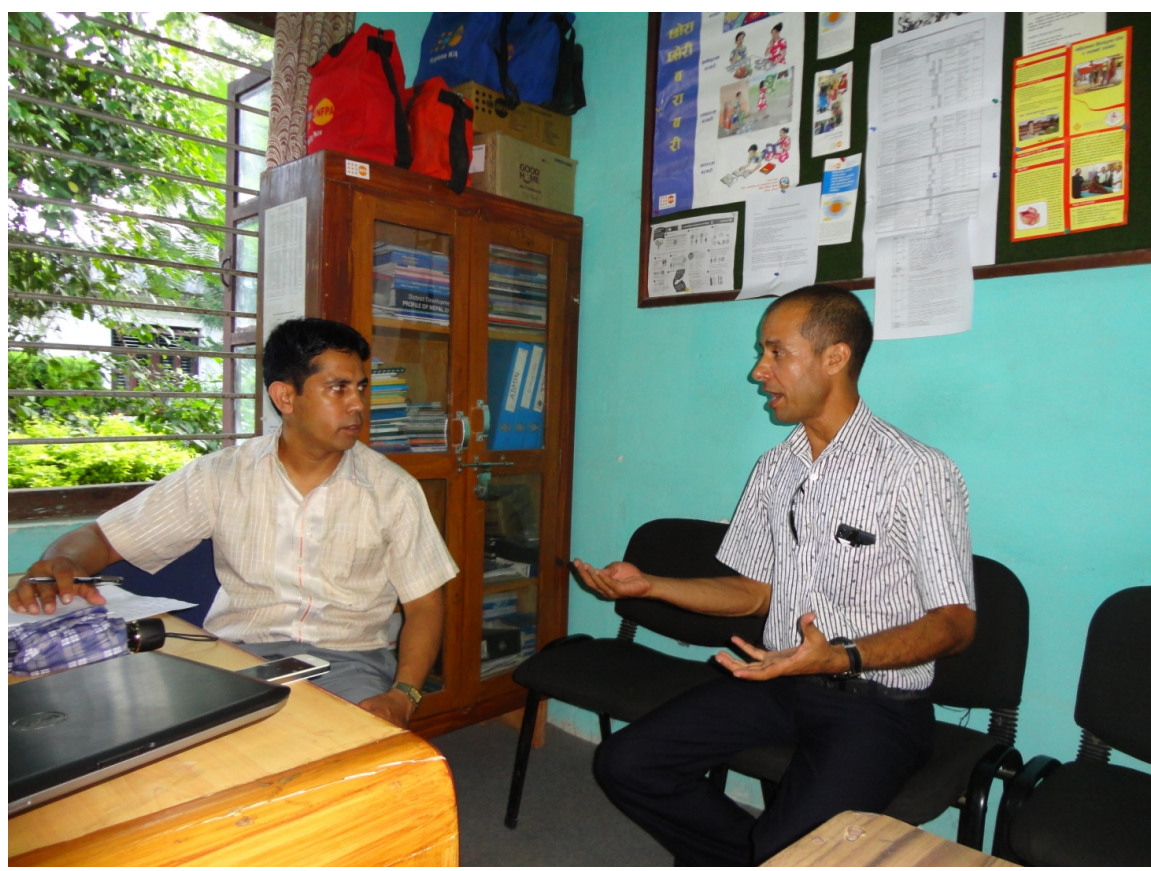

Photo: KII with DDRC member at DDC office of Sindhuli District

First 15 days, DDRC had recorded relief distribution package and made the mechanism for equal distribution, he said. The DDRC could not manage this task for a long time because the interest and priority area/groups of the supporting agencies and individuals were varied and they distributed their own in- 
terest in their priority areas. He opined that some of the settlement of Majuwa, Baseshwor, Bhimeswor, Purano Jhagajholi are in the discussion for resettlement because those settlements are highly affected and damaged by earthquake but not confirmed.

\section{Conclusions and Recommendations}

About fifty percent houses were completely damaged by the earthquake in Sindhuli. Thirty five people were death in and out of the district during the earthquake period. Female death was higher than male among them. Moreover, maximum people were facing injuries. The livestock death and injuries were also found. Women and children, adolescent girls, elderly people and persons with disabilities were more suffered and vulnerable than others. The screening survey found that the earthquakes have unevenly affected the age, gender, poorer, rural locations relative to the urban and less poor areas. It also found that women and children have comparatively fallen victim to anxiety, trauma, depression, feeling helpless, loss of interest (passive) and irrational fear. Children did not go to school because they felt helpless. The rumors of earthquake also found prevalent in the study area.

The rescue and relief package distributed by the state and non state actors were satisfactory. The DDRC had managed the distributions of relief materials and foods through one door policy. Some of VDCs has facing political conflict in the distribution of relief package from the government. During the screening survey, the study found that the NGOs, INGOs, Private and Personal support agencies/actors had played significant role in distribution of relief package in Sindhuli district. The distributions of relief materials were challenging because of the remoteness of many villages in Sindhuli district. Emergency relief and humanitarian assistance to the affected population were provided with the active support of and contribution by multi donor agencies, INGOs, NGOs, private agencies and individuals.

The screening survey has recommended the following issues for large scale study purposes:

- The study can be focused to assess the impact of earthquake on women, children, elderly people and person with disabilities.

- The study should be aware on nutrition, health, hygiene and sanitation issues.

- The study should be incorporated the issues of RH, abortion, miscarriage and occupational change.

- The study should address the question about; what are the coping strategies of vulnerable people during emergencies?

- The study should find the question on: to what degree do humanitarian actors address the needs of earthquake survivors?

- The study should be included community perception on government support after earthquake. 


\section{Acknowledgements}

Author acknowledges to all participants who were keenly participated at the time of information collection.

\section{References}

[1] Nepal Disaster Risk Reduction Portal, Government of Nepal (GoN) (2017) Nepal Disaster Draft Report 2017: The Road to Sendai. Government of Nepal, Kathmandu.

[2] UNDP (2009) Global Assessment of Risk: Nepal Country Report. United Nations Development Programme (UNDP), Kathmandu.

[3] Mishra, S. and Aryal, D. (2015) 1934 Earthquake Revisited: A View from the Archives. Annual Conference on Nepal and Himalaya, Kathmandu, 22-24 July 2015.

[4] Khawas, B. (2015) Post-Quake Nepal: An Appraisal. Sikkim Express, Gangtok, 2 July 2015, 5 .

[5] Center for Excellence in Disaster Management and Humanitarian Assistance (2015) Nepal Disaster Management Reference Book. https://www.cfe-dmha.org/DMHA-Resources/Disaster-Management-Reference-Ha ndbooks

[6] Ulak, N. (2015) Nepal Earthquake 2015. Its Impact on Various Sectors. The Gaze: Journal of Tourism and Hospitality, 7, 58-86. https://doi.org/10.3126/gaze.v7i0.15120

[7] National Planning Commission, Government of Nepal (NPC/GON) (2015) Post Disaster Needs Assessment. National Planning Commission, Kathmandu.

[8] Central Bureau of Statistics (CBS) (2003) Population Monograph 2001. Vol. 1. Central Bureau of Statistics, Kathmandu.

[9] Central Bureau of Statistics (CBS) (2012) National Population Census Report 2011. Central Bureau of Statistics, Kathmandu.

[10] District Development Committee (DDC) (2013) District Profile of Sindhuli 2013. Government of Nepal, Sindhuli District Development Committee, Sindhuli.

[11] District Health Office (DHO) (2012) Annual Report 2011/12. Government of Nepal, Sindhuli District Health Office, Sindhuli.

[12] UNDP (2004) Nepal Human Development Report 2004: Empowerment and Poverty Reduction. United Nations Development Programme, Kathmandu.

[13] District Disaster Relief Committee (DDRC) (2015) Preliminary Records on Earthquake 2015. District Disaster Relief Committee, Sindhuli. 